\title{
General Election: Between Money Politics and Political Identity
}

\author{
Ahmad Taufan Damanik \\ Department of Political Science, Faculty of Social and Political Science, \\ North Sumatera University, Medan \\ taufandamanik@yahoo.com
}

\begin{abstract}
North Sumatra is a richly multi-ethnic province is made up of dozens of ethnic groups, both indigenous to the province and migrants or their descendants. Overall, groups 'indigenous' to the province make up about 36 percent; the rest are migrants where the majority of them are Javanese. Although the city famous pluralism and openness, as well as money politics is rampant, primordialism sometimes a factor in local politics. In the mayoral election in 2010 in the city of Medan, for example, although most of the city's Muslims recently that Rahudman Harahap background questionable when it comes to honesty, there is a campaign that is very powerful and effective way to mobilize their support behind him, given that his rival in the second round mayor race is Sofyan Tan, an ethnic Chinese and Buddhist. Ethnic Chinese and, to a lesser extent, non-Muslims also rallied behind Tan, though not so openly (Aspinall, Warburton and Dettman 2011). As stressed throughout this paper, the choice of a system of Proportional Representation (PR) lists open intensive level of competition between the candidates, especially between candidates of the same party. One interesting result, in the field as in many other parts of the country, is the high level of turnover positions: for DPRD Medan for example, only 30 per cent of the successful candidates were established. Patronage is important, though it comes in many forms - not just the distribution of individual gifts and cash, but also long-term social assistance program that the candidate has in some cases been providing for years. As a result, it tends to only the wealthiest candidates - those who have significant personal assets they have, or can borrow or take donations from relatives or rich sponsors which has a strong chance of victory. Only a few candidates entered the political rivalry with clear ideas on development policies or government programs.
\end{abstract}

Keywords: Political Party, Parliament and General Election

\section{INTRODUCTION}

Many experts relate the practice of corruption with money politic when it comes to struggling for a position through election. The liberal democracy era has pushed money politic intensely that certainly give impact on the practice of corruption to keep growing, as well as on manipulation in government. Consequently, legislative general election then find money politic repeatedly done, not only in a form of vote buying, but also in some other forms, such as programmatic politic, pork barrel, and many others. Although the organizer of the general election has firmly notified that money politics is not allowed, rules and monitoring system still could not fully prevent and take measures on this offense. Internally, not all the political parties are willing to take some steps to overcome it. Instead, they tend to keep it on going continuously. Interestingly, the money politics or patronage is not in line with political identity. Research findings in North Sumatera show that political identity is used as a tool to distribute patronage and also to strengthen it. In this context, patronage distribution and political identity may lead to a dispute either in intra party or in external party. The symbols of group, belief, or other ethnic identity are used to strengthen distribution and at once to broaden a network of candidate's supporters.

A special case occurred in Chinese community, particularly those who are joined in a social organization of Chinese community named PSMTI (Paguyuban Sosial Masyarakat Tionghoa Indonesia). The critical issue in this case was that legislative candidates did not do patronage on their own cost, but passed the cost on to PSMTI who raised fund from their community and from their respected leaders of Chinese community. Moreover, in reviewing the back ground as well as the profile of candidates through the internal 
election, they were financially supported by the Chinese community and certainly by a significant

\section{The condition of social cultural of North Sumatera}

North Sumatera is feasible to be considered as a miniature of Indonesia. The figure of 13, 2 million as a total number of its population explains the percentage of various ethnic people in Indonesia. There are 38 percents of native which is divided in this following figures: Toba Batak $(19,44$ percent), Mandailing (6,32 percent), Simalungun (2,72 percent), Karo (6,64 percent), Pakpak $(0,16$ percent), Nias $(0,40$ percent $)$ and Malay (7,63 percent). Obviously, ethnic people who are originated from outside Sumatera, are at the highest percentage (60 percents) which respectively covers Javanese (44,66 percent), Chinese $(3,63$ percent $)$, Minangkabau $(3,30$ percent), Acehnese (1,26 percent) and some other ethnic groups like Hindi, Arabic and Banten.

It clearly shows that diversity seems so predominate in Medan. Javanese is on peak with its 33 percent, followed by Toba Batak $(20,9$ percent), Chinese (10,7 percent), Batak Mandailing (9,35 percent), Malay (6,6 percent), Karo (4,10 percent), Aceh (2,78 percent) followed by the other ethnics like Arabic, Tamil, Simalungun, Sunda and some others. Even though the diversity is so predominated that social bulkheads occasionally may reveal in social relationship, or in a situation when it comes to choosing living hood, also in government political, fortunately, they could still live in harmony.

However, primordialism in politic and in government is tightly knotted in which religion is primarily does matter. In Medan mayor election on 2010, for example, religious primodialism strongly rose up, particularly in the second round of the election. That was when Rahudman-Eldin (moslem Mandailing- Melayu) were up against Sofyan Tan-Nelly (Buddhist Chinese-moslem Minangkabau). Although Rahudman had bad reputation (finally being sentenced by KPK (Commission of Anti Corruption) due to corruption he committed), while Sofyan Tan was known clean and that he has a strong sense of percentage of votes as well.

social care, still the moslem leaders mobilized people from village to village and persuaded them to be supporters for Rahudman-Eldin to defeat Sofyan Tan-Nelly. Similarly, primodialism also coloured governor election. Gatot-Erry, supported by PKS together with the force of moslem society organization, gained a large votes in east coastal area of North Sumatera, an area where moslem people are the majority. Although Tapanuli and Nias Selatan are not mostly moslem, but by the support and the effort of the regent, Gatot-Erry could win the election. Meanwhile, their rival, Effendi Simbolon-Jumiran Abdi (Christian Tobamoslem Javanese, supported by PDIP) gained large votes in west coastal of North Sumatera. Symbols of religion (although not in use to beat their rival), is still used to empower the image of each candidate.

Therefore, it is clear that beside primordialism, the other factors like money politics, key figures, such as religious leaders and local bossisms as well as the advantage of using bureaucracy, also play roles. It means mobilization of supports is not always single. Yet, it is necessary to note if there are dominant factors between various factors that give influences.

\section{Research Methodology}

This research applies qualitative methodology, and in some cases use shadowing approach by following some selected respondents to know how they set out plan or scenario to win election, how they arrange their success/winning team, how they design the forms and the patterns of patronage distribution, also to set the strategy of how to keep up clientelism, campaign model, and so on. Moreover, researcher conducted an indepth interview with the candidates, success team, and some local people, to deepen the previous output. 


\section{OUTPUT}

\section{Election Winning Strategy on the basis of Socio Cultural}

Legislative election that uses open proportional system stimulates a venomous battle, not only between candidates of different parties, but also mainly, between candidates of the same parties. As a result, surprisingly, in the 2014 legislative election for DPRD Medan, 70 percent new comer in politic won the election, some of them are still young and are lessexperienced in politic. ${ }^{1}$

The key to success began from selecting candidates of regional election before setting winning strategy. Sofyan Tan, for instance, the PDIP legislative candidate for national parliament (DPR RI) in the local election regional 1 (Medan 1 and 2, Deli Serdang, Serdang Bedagai and Tebing Tinggi) stated, "Based on my experience in the 2010 mayor-election, the main basis of my supporters are Chinese who mostly are in Medan." 2 Sofyan was partnered with Brillian

\footnotetext{
${ }^{1}$ Some popular and incumbent candidates, such as Conrad Parlindungan Nainggolan, a senior leader of Golkar and vice chair of DPRD Medan, a very well known incumbent from Demokrat Party, Sutan Bhatoegana, Ramadhan Pohan and Abdul Wahab Dalimunthe also failed in competing with their rivals in their internal party. Compared with the young newbie Politicians such as Prananda Surya Paloh, who is still very young (Nasdem Party), the seniors mentioned above are less pre-eminent. Similarly, Leo Nababan, the vice general secretary of DPP Golkar, native leader, still got less votes than what Meutya Hafid , a young politician and non native but who was supported by the power of local clientielism. Leo Nababan, got less votes than what another new comer from Golkar, Ahmad Himawan Buchari, the son of an Acehnese entrepreneur, who eventhough couldn't reach Senayan. The same with new comers in the province DPRD, H.Ajie Karim from Gerindra who defeated his senior Yan Syahrien from Langkat district, Ichwan Ritonga and Surianto, both represent Gerindra Party, who got a vice chair for DPRD Medan passing by senior candidates and incumbents, as well as Ratna Sitepu from Hanura.
}

${ }^{2}$ In interview with Sofyan Tan about strategic selection on winning election region. This selection was proven successful. Sofyan Tan and his companions achieved main votes in subdistricts where Tionghoa people are the majority. Sofyan Tan reached the point 113.716 of votes, which was far beyond the point his party - companion, Irmadi Lubis who reached 46.039, also far beyond the number of votes the other parties could achieve. The biggest point was winning achieved by Sofyan Tan from Medan, that was 88.017 mainly from Medan Timur, Medan Sunggal, and Medan Petisah which all are the main basis of his supporters who participated in the 2010 mayor-election. The rest came from Tionghoa community in the other three districts.
Mochtar, Hasyim dan Wong Chun Sen, candidates from PDI-P who represent Tionghoa community, Paguyuban Sosial Masyarakat Tionghoa (PSMTI). Brillian Mochtar is for provincial parliament of North Sumatera (DPRD Sumatera Utara) while Hasyim and Wong Chun Sen are for city parliament of Medan (DPRD Medan). The four successfully gained significant number of votes, so they deserved seats in DPR RI, DPRD Sumatera Utara and DPRD Medan. ${ }^{3}$

Candidates from the other social groups also established the basis of main supporters and additional supporters. Tahan Manahan Panggabean was partnered with Ruhut Sitompul and Parlaungan Simangunsong, legislative candidate represented Toba Christian. They focused on seeking for supports from Christian society. ${ }^{4}$ Tahan M Panggabean also explained, "I did socialization not only in Protestant society. We also have a good relationship with other societies at all social level, as well as with Moslem society. A few days ago, we arranged a social event and planted trees in Sunggal mosque. The event was attended by lots of moslem people".5

Similar event was also arranged by Conrad Parlindungan Nainggolan, Toba Katholik, by establishing PASADA (Unity and The Development of The Tradition and Culture of Batak). He also approached Moslem voters by helping them in building mosque. $\mathrm{He}$ was partnered with Ibrahim Sakty Batubara, DPD candidate, the former legislative of Partai Amanat Nasional and Muhammadiyah local leaders. The same approach was also chosen by Hasyrul Azwar from PPP who established Moslem basis

\footnotetext{
${ }^{3}$ It is different with Tionghoa legislative candidate of INTI organization and unsuccessfully in settling the winning strategy, it was only Sonny Firdaus, a Tionghoa legislative candidate from Gerindra who passed while Jan Lie, Lily MBA (both Petahana), also from INTI, failed. Tony Chandra, as well as Eddy Suwandi through Demokrat, and Iskandar from NasDem, the founder of PASTI, new organization for Tionghoa, unsuccessfully implied his strategy.

4 Tahan Manahan Panggabean, the general secretary of Demokrat Party, Medan, and also a senior leader of Christian Youth organization. He is also one of the key leader of the Pro Tapanuli development strike incident in DPRD house which caused the death of DPRD-Sumut chairman 2004 - 2009, Abdul Azis Angkat. Strangely, Tahan Manahan, unlike the other actors who were to jailed for $2-10$ years was set free and could have a seat in DPRD that his name ever crossed. ${ }^{5}$ Interview with Tahan Manahan Panggabean, March 15, and
April 7, 2014
} 
throughout Moslem social organization network. The other Moslem legislative candidates are: Ikrimah Hamidy (PKS), Ratna Sitepu (Hanura) and Effendi Syahputra (Hanura) also did the same while Dr. Geeta, the legislative candidate of Nasional Demokrat, maximized the supports of Hindi people, but she needed to enlarge supports for moslem women's religious activities and Christian community since the segment of voters are from ethnic groups which is relatively small. ${ }^{6}$ Meanwhile, the sociological condition of voters who are mostly Moslems gave them more advantages since the basis of winning team offered more options. The sociological condition region of North Sumatera 1 (Daerah Pemilihan 1) is different from the second and the third which have more districts and sub districts, geographically separated, hard to reach, and have different socio-cultural map which is distinguished from one district or sub districts to the other district or sub districts. ${ }^{7}$

\footnotetext{
${ }^{6}$ However, by her unfamiliar figure, less intensive program, not solid teamwork, and limited fund, Geeta is unfortunately unelected. Likewise, Selwa Kumar, from Gerindra had faced the same difficult circumstance as Geeta had. She failed at being North Sumatera Parliamentary Chair.

${ }^{7}$ For instance, the second constituency, consisting the region of Labuhan Batu Utara, Labuhan Batu and Labuhan Batu Selatan, that mostly consists of ethnic Mandailing, Javanese, Malay, and majority are Moslem, added with some areas that categorized in South Tapanuli, South Padang Lawas, North Padang Lawas,Padang Sidempuan, Mandailing Natal district (Mostly Mandailing and Moslem) along with five districts/sub districts in Nias with diversed ethnic group such as Nias and Christian. This constituency is either a region with mostly ethnic Toba Christian (North Tapanuli, Humbang Hasundutan, Toba Samosir and Samosir district), Middle Tapanuli and Sibolga that has a mixed with Toba, Mandailing, Nias, and another ethnic are fairly Moslem and Christian. A social composition and geographical location prompt candidate to pick up their main region their winning terrain. Gus Irawan Pasaribu, a chairman of Gerindra, a public figure, an ex president director of PT Bank Sumut, and a defeated candidate of North Sumatera governor, had gained the most votes out of all legislative candidates, but it was still Tabagsel, his hometown, where his brother was officiating as a regent, followed by Labuhan Batu, Labuhan Batu Selatan, and Labuhan Batu Utara, with Moslems in it, granting him for the most votes. Furthermore, in a third constituency, they persuade the candidate to decide where their winning terrain should be. Junimart from PDIP, for example, had successfully gained his winning votes from Simalungun district, his own hometown. Other, Rudi Hartono Bangun, and Delia Pratiwi Sitepu had gained their votes in Langkat, their hometown. It was such a good combination reckoning both are having placement parent
} so they would complete each other.

\section{Success/Winning Team}

The next step was to set out winning team/success team. Usually legislative candidate make approach to people who have close relationship with organization or primordial network which has personal closeness with legislative candidates. Only a few of them chose relationship based on professionalism. Organization of success team is not too formal, a bit closed and flexible depends on the needs of political development which is dealt with. However, there are also some who make organization in a relative normal way. Amiruddin, the founder of Rumah Cerdas, which is managed by his son, Destanul Aulia., has established Rumah Cerdas since two years ago. Rumah Cerdas actively do social activities by hiring staff who are well paid. "We are inspired by the NGO concept that is to develop society and to help people who next will prepared to be supporters for his father", Destanul explained. ${ }^{8}$

In winning team, there are always core members which usually consist of credible persons. In the core team of Sofyan Tan (excluding volunteers which are quite many), there are some persons who specifically functioned as political analyst, media, manager, and lobby team to make approaches to the leaders of Chinese community as well as Chinese business men. The other legislative candidates are not to establish a formal success team; personals maybe changeable depending on growing needs from time to time. Not all of the members of core team are paid routinely nor in other forms of wages.

Sofyan Tan and Brillian Mochtar have some members in their winning team who work with the same idealism as a social activist. Wahyudi, for example, one of the leaders of Sofyan Tan's winning team, also a senior leader of NGO who know well and support Sofyan Tan's thoughts. "I've been interested in Sofyan Tan's thoughts for so long, and we have known each other as NGO's ctivists, therefore, I gave him my hands since he participated in mayor election. Although lots of people criticized me for standing up for Chinese

\footnotetext{
${ }^{8}$ Interview with Destanul Aulia, Initiators of "Rumah Cerdas" for her father's winning election, Amiruddin, Medan DPRD Chairman, onwards for legislative election, 2014, on 20 March 2014.
} 
people, I hold my believe that this struggle is important for a new political awareness in North Sumatera." Wahyudi argued in explaining why he is willing to be the leader of Sofyan Tan's winning team. Similarly, J Anto, a well known figure in media is also interested in Sofyan Tan's thoughts. Even though he is Chinese, he, as an activists and journalists, helped Sofyan more because they have similar ideas to fight for ${ }^{9}$

\section{Patronage Schemes}

There are several schemes of patronage distribution to intensify support. Some candidates had implied them in a various formats. Sofyan Tan, for example had built basis of support through social activities that was managed by his team, NGO, his education institution, or PSMTI. The social and political approaches are combined which then eventually would be establishing a political-support basis.10

However, in socialization session, Sofyan Tan was regularly running health care service program, awarding, scholarship and economic support for poor families. He admitted that consistently provide contribution to individuals or organization on his own cost. Unlike the approach mentioned above, when he catch up a gathering with his Chinese societies, the gathering was normally initiated and funded by those who invite him then in. If they were impressed by his speech, they would easily collect money for his campaign. Thus, he got financial support from the elites of Chinese and also from the fellows of communities, besides receiving voting supports from his society. ${ }^{11}$

The same thing happened to Hasyim and Brillian Mochtar that are members of PDI-P and PSMTI. PSMTI took responsible to raise fund which is used to finance campaigns and to help

\footnotetext{
${ }^{9}$ Interview with Wahyudi on 2 and 10 April, 2014 and J. Anto on 15 February 2014. In addition, J Anto helped Sofyan and Perguruan Iskandar Muda to get a Maarif Institut reward for Sofyan and YPIM's efforts in pluralism education in 2014.

${ }^{10}$ Tempo magazine had listed Sofyan Tan as one of the cleanest eleven legislative candidates, education struggler, and multiculturalism. Maarif Institute had also rewarded YPIM of Sofyan Tan for his effort in multiculturalism aspect.

${ }^{11}$ Sofyan Tan would firstly select a businessmen's contribution. He would claim only for a clean businessman, not a black conglomerate. Most donators are middle up businessmen in Medan
}

poor people. Darson and Halim Lo are responsible on raising fund for Sofyan Tan, Brillian, and Hashim. According to Derson, Brillian became poorer because he had spent much for helping the poor people on his own pocket, his business collapse.12

This pattern was also used by Suryanto, a new comer from Gerindra in DPRD Medan. He used his own money to help people who then became his supporters. As a result, he became the second highest achiever of votes. He believed that doing goodness is a blessing as what he said.13 "He did not only help ones who are still alive, but also who already passed away by buying a land for public graveyard." 14

It was still less than two weeks before the election day, he had cashed out 1,2 billion for the needs on his campaign. Yet, he still had to pay more than eight hundreds of witnesses for ballot boxes, operational costs, winning team costs, and giving-out food and other materials for the poor. He even gave more to non-Javanese and nonMoslem. ${ }^{15}$

Meanwhile the incumbent candidates like Brillian Mochtar (PDIP) and Ikrimah Hamidy (PKS), besides giving out social donations, both of them take advantages of their former position as parliament member by overcoming problems found in the election region. Ikrimah, largely help merchants, non permanent teachers and groups of disabled by using the policies he initiated formerly when he was the vice chairman of parliament. Brillian largely give assistant to the cases of labour, poor people and also Chinese people. Some of infrastructure program are successfully fought for in the election regions.

However, this pattern is not really successfully done by Amiruddin, the former chairman of DPRD Medan. Although he had already prepared Rumah Cerdas foundation that manages social program, social donation as well as infrastructure project, he failed defeating

\footnotetext{
${ }^{12}$ Interview of Derson on 27 March 2014, Halim Lo a Chair of PSMTI Medan, confirmation of Brillian Mochtar and Sofyan Tan

${ }^{13}$ Interview and shadowing Surianto, March - April 2014

${ }^{14}$ Interview one of the winning team of Surianto, 5 March 2014. He would explain more about the other social help-up, given it to poors in his constituency.

${ }^{15}$ Interview with Surianto, 31 March 2014
} 
Parlaungan Simangunsong, his rival from the same party. He suspects that there was a deception in the election but there was no proof to claim. ${ }^{16}$

The other incumbent candidate secretly gathered the program of development project (pork barrel) with financial support, materials, and the nine needs staple food for communities. Hasrul Azwar from PPP successfully gained votes to the maximum, yet Tahan Manahan Panggabean, a candidate figure of democracy who is considered as a hero in rising Tapanuli province, failed. Likewise, Conrad Parlindungan Nainggolan, candidate from Partai Golkar for DPRD Medan, claimed that there was a dawn attack and votes manipulation. This accusation is hard to be proven but at least had already pushed the Election Monitoring Council at provincial and city levels to release a recommendation for votes recounting in some ballot stations.

Another thing that is unique was the practice of patronage in the style of Ratna Sitepu from Hanura. Through "Mari Berhijab" or "Let's wearing hijab", Ratna went around from one to another women recitation, motivating and teaching Moslem women how to wear hijab, then distributing the Moslem women's clothing and also foods, facilities for Moslem activities, and so on. Ratna always gave affirmation that hijab program is one of her missionary work. She stated that teaching and distributing hijab is not only because of general election, and that she will keep doing it continuously as it is a part of her missionary and that must be done. ${ }^{17}$. Ratna Sitepu successfully defeated incumbent from Hanura, Budiman Panjaitan (3893 to 3642). Ratna claimed that she would not give out money as what her father, Bangkit Sitepu did,18 let alone paying people for vote manipulation. However, Ratna

\footnotetext{
${ }^{16}$ In 2009 election, Amiruddin was a legislative candidate who reached most of votes (more than 12 thousand) which was far beyond Simangunsong's achievement, that was 11 thousands votes in 2009

${ }^{17}$ Ratna's clarification in some occasions

${ }^{18}$ The legislative candidate, Bangkit Sitepu, as well as Sutan Bhatugan from Demokrat, seperatedly, caught by journalist came, giving out money to the visitors of their party campaign. Bangkit Sitepu, again sit on the chair of DPRD Medan while Sutan failed. Sutan can be said as a legislative candidate who loudly announce in various media about his party companion, Ruhut Sitompul community unfair political practice.
}

must keep facing Budiman Panjaitan by means of Election Monitoring Council who accused her for vote manipulation.

Certainly, there is always practice of vote buying in a various tricky ways; some kinds of vote pander may offer a number of votes that is charged 25 to 50 thousand rupiah or even more per vote. Another way is by paying the persons who are in charged on the voting day. They will be paid for adding votes, changing votes to win the legislative election. The Election Monitoring Council of North Sumatera and Medan have been informed either by legislative candidate or by other source of information. Therefore, the two councils recommend recounting votes in some districts.

The most interesting case ever happened was when some boxes of votes lost in Helvetia district of Medan that the election committee was to be charged before law. Dewan Kehormatan Penyelenggara Pemilu (DKPP) or Honour Council of Election Administrators would also do investigation on four commissioners of Election Commission of Medan points to how widespread these irregularities were. Actually, there was no evidence which clearly indicated this fraud, so it must be examined by DKPP, the monitoring council and the law enforcer. Yet, many media had already reported about many kinds of cases in Medan. The cases were not as bad as what happened in Nias Selatan and Padang Lawas that urgently need re-voting which consequently all the processes of election should be delayed not only in the both districts, but also at province and at national levels. "Somebody claimed that he can set up vote gaining and he charged 1 billion rupiah for additional thousand of votes", said Effendy Syahputra who then decided not to accept the offer since he had not prepared for that. Besides, he suspected about the pander. This was also experienced by other legislative candidates but denied doing it. ${ }^{19}$ Nevertheless, DKPP's decision to fire some commissioners of KPU strongly indicates the fraud.

Winning logistic of each legislative candidate is distinguished not only based on number, but also based on their social status. Some come from wealthy family and therefore they have no difficulties in funding all of the campaign operational, including patronage,

\footnotetext{
${ }^{19}$ Interview Effendi Syahputra, 12 and 20 March 2014
} 
success/winning team cost on and operational. As described above, legislative candidates represented Hanura and Nasdem obtained program from their party by way of insurance program, donated noodles, etc. Some others got a huge donation from businessmen, ethnic leaders and Chinese communities. There was even a special team who was in charge to mobilize financial supports as well as program support (health program, medicines, and medical team) and was also to manage all supports. Some legislative candidates use their power to direct social fund program, infrastructure program to their election regime and then use the program/project to approach electors.

Legislative candidates who are powerful in financial, either or their own, sponsorship, or access to development finance, get more chance to win compared with the other legislative candidate with a limited capacity/insufficient capacity. Effendi Syahputra, eventually had to give up by the d-day of election, since the cancellation of funding promised by his party leader weakened him (make him powerless) in beating his rival. Funding on his own that had he prepared was insufficient. In contrast, legislative candidate also possibly failed even though they are financially strong. It happened because they were not smart enough in distributing donation or mismanaged finance for campaign program.

\section{CONCLUSION}

The observation on the various legislative candidates, at national, province an major level, reveals some interesting politic phenomenons found in the era of transparent election. First, there is a tendency of a political individualist in the election. Legislative candidates by themselves, work on the formulation and the management, and also on their own, fund their winning program. It means that the candidates struggle in personal even though the big name of the party they represent is still influencing. A charismatic candidate who is surely able to achieve the winning target, and who has a strong bounded team and ethnic identity, is the most possible candidate to win the election.

Second, money politic or patronage, is applied in some models, either in a structured way through social projects that is held prior to election, or in an unstructured way based on the social attitudes of the legislative candidates. These helpful social enforcements are safe from traps of rule-surveillance, and also easily get social excuses especially if it is covered with religious activities.

The worst, giving out money directly to the voters (vote buying) and in cooperation with the general election organizers, as well as manipulating votes, are evidently proven to have threatened the party consolidation. It is not surprising that accusations brought to DKPP and to Constitutional Court, are mostly about conflicts between legislative candidates of a same party.

Third, identity politics is also a factor which is mostly relied on to empower winning basis. Identity politics can be established based on ethnic, religion, or on the combination of both. The political contestation the basis of identity could be a foundation in building up clientelism network. Structural network of a party is not much used for it is not considered loyal but expensive and complicated. This finding then would strongly indicate the weakening of the roles of a party in an election, and consequently would threat party consolidation in the future.

Fourth, there is only a few of candidates who come with a big idea of politic issues. The rest are only to compete for power. Unfortunately, the pragmatism which is widespread among the figures of politic leaders and among roots, more strongly force the candidates to , like it or not, playing money politic and politic pragmatism. However, there are still some segments of critical people who objectively value candidates mainly based on their ideas. Even though it is quite a few, this segment of people could potentially be the boosters for political changes or at least for the growing of democracy which is worried to be weakened in this country.

Indeed, qualitative research that tries to figure out the political phenomenon of general election in Medan, still needs to be completed with some other reviews that could widen the dimension of socio-cultural political of Indonesia. It is also necessary to take lead in reviewing the institution of parties, that is how the actors in the parties work, and how the parliament institutions capture/identify the new stream of politic. 


\section{SUGGESTIONS}

This review comes out with some corrections on the strengthening of the future democracy system:

1. Parties need to educate the prepared candidates about the ideology of politic contest or the platform of each party, also about how to tightly and transparently proceedingselection, recruitment and politic promotion that is aimed to be more substantial.

2. It is necessary to re-examine the closed proportional system, where the role of party is relatively strong in determining/defining the candidacy.

3. Strengthening the general election, is not an attemp to strengthen onlyBawaslu and Pawaslu, but also to empower the rules and sanctions, the instrument of law enforcements, as well as the involvement of civils who are under oversight.

4. It is needed to set out a forceful codes of ethic about how far the symbols of religion and ethnics can be applied in campaigns to be able to avoid politic disputes in contest that reduce the substance of democracy.

\section{ACKNOWLEDGEMENTS}

I am so grateful for the supports of Prof. Edward Aspinall from the Australian National University, which is for funding this research and for supervising me. A special thank also goes to Team PolGov of Gajah Mada University, Yogyakarta who is fully involved in guiding the research team including me, who is in charge in Sumatera Utara region, particularly in Medan.

\section{REFERENCES}

Allen Hicken, Clientalism, Annu. (2011). Rev. Polit. Sci. 14:289-310

Benyamin K. Sovacool. (May,2010). "The political economy of oil and gas in Southeast Asia: heading towards the natural resource curse?", The Pacific Review, Vol. 23 No. 2.
Budi Agustono. (2010). Rekonstruksi Identitas Etnik, Sejarah Sosial Politik Orang Pakpak di Sumatera Utara 1958 - 2003, Disertasi Doktor, UGM

Daniel J.Young. (2009). "Is Clientelism at Work in African Elections? a Study of Voting Behavior in Kenya and Zambia, Working Paper No. 106

Edward Aspinall. (2013). "Money Politics: Patronage and Clientelism in Southeast Asia", Draft paper: For William Case (ed.) Handbook of Democracy in Southeast Asia (Routledge).

Edward Aspinall dan Mada Sukmajati (ed). (2016). Politik Uang Di Indonesia, Patronase dan Klientelisme pada Pemilu Legislatif 2014, PolGov-UGM (ed).

Electoral Dynamics in Indonesia, Money Politics, Patronage and Clientelism at the Grassroots, NUS Press Singapore

John, T Sidel. (2005). "Bosisme dan Demokrasi di Filipina, Thailand, dan Indonesia", dalam John Harris, Kristian Stokke, dan Olle Tornquist (ed.). Politisasi Demokrasi: Politik Lokal Baru. Jakarta: Demos

Loren Ryter. (1998). Pemuda Pancasila: The Last Loyalist Free Men of Suharto New Order? Indonesia, 66, October . (2009). Youth Gangs and Otherwise in Indonesia, paper for Global Gangs Workshop, Geneva

Lucian W. Pye. (Mar, 1997). "Money Politics and Transitions to Democracy in East Asia", Asian Survey, Vol. 37, No. 3

Lucian N Leustean. (2005). Religious and Political Symbols in Post Modern Society, LSE

Muriyanto Amin. (2013). "Kekuasaan dan Politik Lokal (Studi tentang Peran Pemuda Pancasila dalam Mendukung Syamsul Arifin dan Gatot Pudjonugroho sebagai Calon Gubernur dan Wakil Gubernur Provinsi Sumatera Utara Periode 2008-2013)", Disertasi Doktor UI

Shinici Ichimura and Roy Bahl. (2008). Decentralization Policies in Asian Development, Georgia State University USA,

Susan Stokes. (2011). "What Killed Vote Buying in Britain?", a paper of a book project, Buying Votes: Distributive Politics in Democracies, co-authored with Thad Dunning of Yale University and Marcelo Nazareno and 
Valeria Brusco of the National University of Cordoba, Argentina

Tahan Manahan Panggabean. (2013). 12 Alasan Memilih Drs Tahan Manahan Panggabean (TAMPAN), Yayasan Tampan

Vedi R Hadiz. (2008). Indonesia A Decade After Reformasi: Continuity or Change ?, National University of Singapore

Vincent P Vecora. (2001). Nations and Identities: Classic Readings, Blackwell Publisher

Wolfgang Muno. (August, 2010). "Conceptualizing and Measuring Clientelism", Paper to be presented at the workshop "Neopatrimonialism in Various World Regions", GIGA German Institute of Global and Area Studies, Hamburg. 